\title{
Prison Litigation and Bureaucratic Development
}

\author{
Malcolm M. Feeley and Edward Rubin
}

Steve J. Martin \& Sheldon EkLand-Olson, Texas Prisons: The Walls Came Tumbling Doum. Austin: Texas Monthly Press, 1987. Pp. 288. $\$ 21.95$.

Ben M. Crouch \& James W. Marquart, An Appeal to Justice: Litigated Reform of Texas Prisons. Austin: University of Texas Press, 1989. Pp. $x$ iii +280 . $\$ 27.50$.

John J. Dilulio, JR., Governing Prisons: A Comparative Study of Correctional Management. New York: Free Press, 1987. Pp. xvi+349. \$27.95.

LARRY W. YACKLE, Reform and Regret: The Story of Federal Judicial Involvement in the Alabama Prison System. New York: Oxford University Press, 1989. Pp. 336. $\$ 35.00$.

In 1871 the Virginia Supreme Court could dismiss the complaint of a prisoner challenging the length of his sentence with the following observations:

A convicted fellow whom the law in its humanity punishes by confinement in a penitentiary instead of with death, is subject while undergoing that punishment, to all the laws which the Legislature in its wisdom may enact for the government of that institution and the con-

Malcolm M. Feeley and Edward Rubin are professors in the School of Law, University of California-Berkeley.

This essay stems from the authors' continuing work on the impact of prison and jail conditions litigation which is supported by the Guggenheim Criminal Justice Program at the Center for the Study of Law and Society, University of California, Berkeley. The authors wish to acknowledge the Daniel and Florence Guggenheim Foundation for supporting this endeavor. 
trol of its inmates. For the time being, during his term of service in the penitentiary, he is in a state of penal servitude to the State. He has, as a consequence of his crime, not only forfeited his liberty, but all his personal rights except those which the laws in its humanity accords to him. He is for the time being the slave of the State. He is civiliter mortuus; and his estate, if he has any, is administered like that of a dead man. ${ }^{1}$

Nine decades later, in 1961, state prisoners remained for all practical purposes slaves of the state. The words were not used, but the substance was the same. Prisoners were without recourse to challenge conditions of confinement in court, and prisons were virtual preserves of correctional administrators who were often wholly oblivious to developments in administration that had affected other state public service institutions and equally oblivious to the legal strictures of an increasingly nationally oriented federal system.

Now three decades later still, every prison and jail in the United States-like other public service institutions-must work within the structure of modern bureaucratic organization. They must consciously consider a myriad of federal standards on a daily basis, either in direct response to federal court orders or in the hope of avoiding them. At least one prison or jail in virtually every state is under a court order. This transformation has been swift and sweeping, beginning with the pursuit of traditional First Amendment and due process challenges in the 1960 s and quickly expanding to challenge conditions of confinement under the Eighth Amendment's prohibition against cruel and unusual punishment shortly thereafter. ${ }^{2}$ Although there is continuing interest in corrections reform, court rulings have reinforced these concerns and given them a sense of urgency. This involvement is hardly unique; prisons and jails may simply be the last of a host of state and local public agencies that have been affected by the rights revolution.

Prisoner rights cases began with First Amendment challenges to prisoners' rights of expression and were quickly followed by cases involving due process challenges to disciplinary hearings, good time credits, and other privileges. But the underlying problem confronting many inmates was much more extensive than the denial of the freedom of expression and due process. It was the totality of their conditions-overcrowded, outworn facilities; overextended staffs; brutality; dangerous conditions; lack of medical and food service; poor sanitation, heating, and ventilation-an

1. Ruffin v. Commonwealth, 26 Va. 720 (1871).

2. For an overview see James Jacobs, "The Prisoners' Rights Movement and Its Impacts," in Norval Morris \& Michael Tonry, eds., 2 Crime and Justice 429-70 (Chicago: University of Chicago Press, 1980), and Malcolm M. Feeley \& Roger A. Hanson, "The Impact of Jail and Prison Corrections Litigation," in John J. Dilulio, ed., Courts, Corrections and the Constitution (New York: Oxford University Press, 1990). 
endless list of problems. Thus it was all but inevitable that lawyers for prisoners' rights groups would turn to the hitherto unexamined provision in the Eighth Amendment prohibition against cruel and unusual punishment to attack these conditions and in so doing attack the very administrative structure of the prison system. ${ }^{3}$

In the eyes of prison officials, the earlier decisions, while bad enough, had been relatively easy to comply with: provide Korans for Black Muslims, allow mail to flow more freely, place law books in prison libraries, develop procedures for handling disciplinary actions, improve lawyers' access to inmates, and the like. But the Eighth Amendment conditions cases were much more problematic. They invited federal judges, in the terminology of Yale Law Professor Owen Fiss, to formulate and implement "structural reform." 4 The remedial orders in these cases sought to infuse prisons, and in some states entire correctional systems, with a new approach which at times constituted a radical transformation, of organizational personality-a transformation that affected every detail of institutional life, from the quality of food, the availability of medical services, and the wattage of light bulbs to the understanding of the basic mission of the correctional system. Despite an increasingly conservative federal bench and a hostile Department of Justice, judicial involvement survived and indeed expanded during the 1980s. ${ }^{5}$

How have the courts fared in their unfamiliar role as structural reformers, and what are the institutional consequences of their involvement? In recent years a trickle of dissertations, articles, and most recently books have begun to address this and related questions. ${ }^{6}$ The value of these studies is that they provide detailed descriptions of how judges, who possess neither sword nor purse, go about conceiving of and supervising complex administrative processes. To the extent that judges in the modern state act as administrators, it is imperative that we understand how this administrative process takes place.

Not surprisingly the case studies in books examined in this review focus on celebrated cases and famous judges. Two of them concern the

3. See, e.g., Rodney Smolla, "Prison Overcrowding and the Courts: A Road Map for the 1980s," 1984 U. Ill. L. Rev. 389.

4. Owen Fiss, "The Supreme Court, 1978 Term-Foreword: The Forms of Justice," 93 Harv. L. Rev. 1 (1979).

5. There were most certainly cutbacks and decisions by both the U.S. Supreme Court and the courts of appeal. Despite this the numbers and scope of cases continued to grow. See, e.g., the periodic bulletins issued by the National Prison Project of the American Civil Liberties Union. Despite the rise of a conservative judiciary, the numbers of suits and institutions under court order continued to grow throughout the 1980 s.

6. An early and impressive effort was the monograph by $M$. Kay Harris \& Dudley $P$. Spiller, Jr., After Decision: Implementation of Judicial Decrees in Correctional Settings (Washington, D.C.: NILECJ, Oct. 1977). The report was a detailed study of the implementation of court orders in four cases. 
mammoth Texas case, Ruiz v. Estelle, ${ }^{7}$ which involved that state's entire correctional system in close to two decades of litigation, and which is the largest and by all accounts the most acrimonious of all conditions cases to date. Steve Martin and Sheldon Ekland-Olson's Texas Prisons: The Walls Came Tumbling Down recounts the history of the litigation process in this case as well as its impact on the prison system. Ben Crouch and James Marquart's An Appeal to Justice is a sustained examination of the institutional consequences of this same case. A third book, Governing Prisons, by political scientist John Dilulio, a general study of prison management, devotes considerable space to the Ruiz case and to prison management in Texas. The fourth book, Larry Yackle's Reform and Regret, examines another almost equally famous pair of cases, Pugh $v$. Sullivan and James $v$. Wallace, ${ }^{8}$ which involved challenges to conditions in Alabama's main prison, and whose protagonists included Judge Frank M. Johnson and his long-standing nemesis, Governor George Wallace. ${ }^{9}$

We will look first at the three books that deal with Texas and then turn to Yackle's study of Alabama litigation, which we believe will help us develop a perspective on the Texas case and conditions litigation and prison management more generally.

\section{Martin \& Ekland-Olson's View of Texas}

Steve J. Martin \& Sheldon Ekland-Olson's Texas Prisons: The Walls Came Tumbling Down is lively reading. After a brief history of Texas prisons between 1849 and 1967, it turns to the litigation process in Ruiz $v$. Estelle, describing its background and the many twists and turns it subsequently took. The story is presented as the vindication of rights by tenacious civil rights lawyers in the face of formidable opposition. One of the authors, Steve Martin, began his career as a prison guard, and eventually became an attorney for the Texas Department of Corrections (TDC). For

7. 503 F. Supp. 1265 (1980). (1974).

8. Pugh v. Sullivan, 406 F. Supp. 318 (1976); James v. Wallace, 382 F. Supp. 1177

9. In addition, there is a growing list of master's and doctoral theses that deal with the problems of implementing court orders in prison and jail conditions suits. Among those we are aware of are Bradley Chilton, "Guthrie v. Evans: Civil Rights, Prison Reform, and Institutional Reform Litigation" (Ph.D. thesis, Department of Political Science, University of Georgia, 1988); Richard Liles, "An Analysis of the Use of Special Masters for Assuring Compliance with Judicial Decrees in Corrections Litigation" (D.P.A. thesis, Center for Public Administration, Western Michigan University, 1987); Anthony Newland, "Managing Prisons: Conditions of Confinement Litigation-Lessons for California Administrators" (Ph.D. thesis, Golden Gate University, 1990); Wayne Welch, "A Comparative Analysis of Court Orders against California County Jails: Intervention and Impact" (Ph.D. thesis, Social Ecology, University of California at Irvine, 1990); Mary Parker, "Judicial Intervention in Correctional Institutions: The Arkansas Odyssey" (Ph.D. thesis, Sam Houston State University, 1985). 
a short time he was involved with the defendant TDC in the case, and by several accounts was a finalist for the TDC directorship.

Nonetheless, the heroes of their story are the plaintiffs' attorneys. Once brought, the case was fortuitously assigned to William Wayne Justice, an intense federal district judge and a liberal appointee of Lyndon Johnson, who had just handed down a wide-ranging order altering conditions in Texas's juvenile facilities. He in turn selected a veteran civil rights lawyer, William Bennett Turner, to represent the plaintiffs.

From the outset the case was more than a complaint about conditions by prison inmates against the corrections department. It was a high-profile fight that pitted the plaintiffs' attorneys, and later Judge Justice and his special master, Vincent Nathan, against what appeared for a while to be the entire state of Texas. At trial Judge Justice found the TDC woefully deficient in six areas: space per inmate, security and supervision, health care, discipline, access to legal services, and sanitation and safety conditions. Although most of these issues were presumably resolved in a courtorchestrated settlement, plans for implementing remedies continued to be bitterly contested.

The most heated issue involved the fact that the consent decrees had not addressed the use of inmates as guards (or, in TDC parlance, building tenders (BTs)), which plaintiffs maintained constituted the core of TDC's system of inmate control. According to Martin \& Eckland-Olson, despite overwhelming evidence to the contrary, TDC officials refused to acknowledge this policy-and hence steadfastly resisted the changes in the administration of security sought by the court-until the state's attorney general was convinced that the allegations were true. They report that this revelation shattered his confidence in the TDC and proved to be the turning point in the case. ${ }^{10}$ Caught in a lie, TDC's officials slowly lost their vast reservoir of public and political support. If the tide did not exactly turn in favor of Judge Justice and his special master, at least Texas officials began to look skeptically at TDC practices and take steps to bring in new prison administrators who would acknowledge TDC's problems and commit themselves to implementation of the court's orders. All this took place during a period of unprecedented population increase within the state's prisons, and the court had to add this to the already long list of problems it was dealing with.

10. The moment of revelation is presented dramatically in Martin \& Ekland-Olson's book; according to the book the key information was provided by one of the authors, Steve Martin, who at the time was a lawyer for the director of the Department of Corrections. As a former guard and long-time correctional employee, Martin was well aware of the crucial role played by building tenders. He asserts that the turning point in the public feature of the case came when he went to the attorney general, who up until then had believed the TDC claim that building tenders had no supervisory control over inmates, and informed him that in fact department officials were lying. 
The court-ordered changes were traumatic for the Texas prison system. They required massive increases in expenditures for new facilities, plus new positions, population caps, and early releases. Indeed they required creating a new and different organizational structure with new leadership and a different administrative structure. And they required the continued presence of an outspoken judge and his special master, whose intrusiveness was deeply resented.

With the dismantling of the building tender system, the loss of some of the older and more accomplished administrators, and the rapid influx of new and inexperienced correctional officers, staff morale and discipline declined, and staff turnover skyrocketed. At the time the litigation commenced in the mid-1970s, TDC administrators could do no wrong in the eyes of the state. But by the early 1980s, it appeared that the TDC could do no right. Reports of the special master continued to find failings and noncompliance, and related state investigations unearthed other scandals. One result was turmoil among both staff and inmates.

One of the most devastating features of this turmoil was the precipitous increase in inmate-to-inmate violence. Between 1980 and 1985, killings escalated to an all-time high. Martin \& Ekland-Olson place responsibility for this increase on the intransigence of TDC officials in acknowledging and dealing forthrightly with the corrosive features of the building tender system, despite reported warnings from Judge Justice.

However, by late 1985 a new stability had been established. It came after a cadre of new top administrators recruited from outside the TDC was firmly ensconced; after the hundreds of new guards who had been hired to replace the old building tenders gained experience, confidence, and guidance; and after massive increases of funding and building construction had been approved by the state legislature.

\section{Crouch \& Marquart's View of Texas}

Although their account lacks the drama of Martin \& Ekland-Olson's story with its larger-than-life personalities, Crouch \& Marquart provide a solid institutional analysis which explores the changes wrought by the Ruiz case. Theirs is a classic before and after-or more accurately a before, during, and after-study that seeks to identify the impact of the litigation on the institutional structure of the Texas Department of Corrections.

Focusing on the response of the TDC leadership and staff in one of TDC's several prisons (a "unit" in TDC terminology) clustered around Huntsville in East Texas, Marquart \& Crouch chart the change from a traditional "repressive" and tightly administered correctional system to a modern "bureaucratic" system. For a brief transitional period, they characterize the system as being a "legalistic order," by which they mean that it 
was highly centralized and hyperlegalistic. Their book can be divided into three parts, corresponding to these three forms of ordering (and which are summarized in a valuable concluding chapter).

The distinguishing feature of the old "repressive order," which found its fullest expression under the leadership of O. B. Ellis (TDC director from 1947 to 1961) and George Beto (director from 1961 to 1972), was total control over the inmates. Discipline was strict, and the mass of inmates was subordinated through the use of inmate elites, the BTs, who were granted extensive coercive powers over other inmates. The prison was run by the personalistic leadership of TDC directors and wardens and the discretionary practices of its correctional officers.

In one way this system had worked well and had been well regarded. Within the state, Beto had been lauded as an outstanding administrator and had been virtually immune from serious attack. And throughout the nation, the neat and orderly prisons in the Texas system had an enviable reputation as being among the very best. At least officially, inmates in Texas prisons were safe, secure, and well fed. Had it not been for this sterling reputation, it is unlikely that the TDC would have been able to mobilize such political support for its position and have been so successful in resisting the court for as long as it did.

Litigation precipitated an institutional crisis, one that had profound impact on the institutional structure of the Texas Department of Corrections. ${ }^{11}$ Like Martin \& Elkand-Olson, Crouch \& Marquart emphasize that the court's order affected TDC's very institutional being, its organizational style and ethos. By attacking the BTs, the court in effect ordered TDC to dismantle one of the foundations on which its success and reputation had long rested.

Judge Justice did not set out directly to restructure the administrative and staff structure of the Texas Department of Corrections. But his order requiring that the building-tender system be dismantled had this effect because it ended the informal system of personalistic rule on which the old order rested. Most of Crouch \& Marquart's book deals with descriptions of the "old order," the paternalistic and repressive regime that prevailed prior to Ruiz, and with the interim "legalistic order" from 1982 to 1985, during which the TDC experienced turmoil as administrators, staff, and inmates sought to come to grips with the implications of the changes that had been imposed on them.

The most fascinating feature of Crouch \& Marquart's account is their analysis of the administrators' efforts to cope with staff and inmate

11. The litigation also commenced shortly after Beto retired and was replaced by James Estelle, who had not previously held positions in the TDC and had a quite different administrative style. It is interesting to speculate just how much of the dislocation and administrative turmoil was a consequence of problems of succession. 
responses to the passing of the old order. These changes created a vacuum in the control structure of the prison system. With the demise of the old way of doing things, veteran TDC staff became disillusioned-some resigned and others stopped caring. New staff were inexperienced and disorganized. The abolition of the building-tender system meant that these disillusioned or inexperienced staff members could no longer rely on a coopted inmate elite to control other inmates. Furthermore, with both the court and its special master, as well as various state officials, looking carefully over their shoulders, top TDC administrators initiated an administrative shake-up which resulted in a number of resignations, dismissals, reassignments, and a regime of micro management from the top down that further undermined morale and effectiveness.

These changes reinforced each other and together promoted social disorganization among inmates, among staff, and between the two groups. Predatory inmate gangs emerged and began doing battle with one another. "To protect themselves in an increasingly uncertain world, many inmates resorted to violent self-help, and in the process violence became a mechanism of social control"' (at 199). The old order had depended on relentless surveillance by a totalitarian system that created a docile and passive inmate population; when it was dismantled, there were no control mechanisms to replace it. This demise of the old system led to uncertainty and ambiguity and ultimately to a dramatic increase in inmate-to-inmate violence.

By 1985, however, a new order had emerged. Crouch \& Marquart describe the recruitment of a new group of top administrators, largely from outside the TDC and many with military experience, and the emergence of a new stability based around the principles of bureaucratic accountability. They marshal data from interviews with long-term inmates to argue that under the new order inmates-whites, blacks, and Hispanics-feel that the TDC is a safer and more stable environment than it had been under either of the two preceding regimes. Figures on inmate homicide rates and disciplinary actions reinforce these perceptions. ${ }^{12}$

Crouch \& Marquart attribute the reemergence of control and stability in the prison system to the reassertion of decisive leadership. Unlike the earlier regime, however, it was an organization built around and committed to bureaucratic rather than personalistic control. And it was a leadership that established two conditions; first, the use of administrative segregation and lock-down as means of dealing with escalating gang vio-

12. At 216 they state that "homicides in TDC fell from twenty-seven in 1985 to five and three in 1986 and 1987, respectively [lower than they had been in many years]." Similarly disciplinary cases involving weapons dropped from a high in 1985 to less than two hundred in 1987 (id). 
lence, and, second, the elimination of staff power to informally impose sanctions on recalcitrant prisoners.

But this new order, although producing some impressive immediate results (dramatically reduced rates of violence) depends heavily-even as of this writing several years later-on administrative segregation and frequent lock-downs. Furthermore even this was achieved only because of extraordinary measures and massive increases in the TDC budget. Despite the authors' acceptance of the "new order," it is not clear that it has taken root. It is costly, and in face of the state's economic downturn, the continued growth of the state's prison population, and the inevitable decline of public scrutiny of corrections, it remains to be seen whether this new system will flourish or whether some version of the old order will reassert itself.

\section{DiIulio's View of Texas}

John Dilulio's Governing Prisons also deals with the Texas litigation, but in a different way. Unlike the other two books, his is neither primarily about prison litigation nor about the Texas prisons. Although he focuses on the Texas case at great length, the book is about management of prisons, more particularly about good management. His basic thesis is that the sociologists have made a mistake in claiming that "inmates run the joint" and inevitably must run the joint. In contrast, he embraces the wisdom of political scientists, whose value, he argues is that they believe that "prison management matters" (at 255). Much of his book is dedicated to demonstrating the proposition "that good prisons are possible" and denying the proposition that "bad prisons are inevitable." Dilulio contrasts decidedly different management styles in different prisons across the country; controlling as best he can for types of offenders, size of institution, and other factors that might account for differences, he shows that organizational structure affects the conditions of prison life. The more hierarchical and formalized the structure and the clearer the division of labor in superior-subordinate relationships, the better the operations. In seeking to put this to test in prisons, he continues:

The proper unit for analysis is less the correctional agency as a whole and more the prison itself; not who reports to whom at headquarters but who works how in the institutions. Contrary to the argument made in much of the existing literature, the best hypothesis seems to be that higher-custody prisons that are organized along bureaucratic, even paramilitary, lines and operated strictly "by the book" will have less violence than those that are organized and run more loosely. A corollary to this hypothesis is that reliance on in- 
mates to control other inmates ... is a recipe for compromising security and violating laws. (At 237)

These are important observations, but apart from those who don't like the idea of prisons at all, few would disagree with them..$^{13}$

What is striking and controversial about Governing Prisons is Dilulio's example of the "best-case" prison administration. Dilulio chooses the Texas Department of Corrections, in its pre-Ruiz days-the "old order" as it were. The hero in his story is George Beto, and the villain is Judge Justice, whose incompetence, he asserts, was largely responsible for the demise of an exemplary system of prison administration and the ensuing violence and turmoil.

In offering this interpretation, Dilulio stands the views of the authors of the other two books about Texas prisons on their heads. Although they emphasize different issues and diverge in certain ways, the others agree that before the Ruiz litigation Texas prisons were violent, repressive, and dangerous, nominally run by a powerful director, but in fact controlled by an elaborate staff-sanctioned system of inmate thugs. In both the other books, the TDC emerges as something of a Potempkin's village, presenting a clean and well-ordered façade to the casual observer but subjecting the inmates who lived in it to a brutal, repressive and dangerous reality. In both books pre-Ruiz prison organization was personalistic and prebureaucratic, virtually the antithesis of the institutional arrangement Dilulio endorses. ${ }^{14}$ As this regime is presented in the other two books on Texas, its leadership, in Weberian terms, was a combination of traditional and charismatic.

Because Dilulio sees George Beto and the pre-Ruiz TDC as the model for modern prison systems, he condemns Judge Justice for having disrupted the system through his excessive zeal and incompetence. Dilulio begins with a tempered assessment:

[W] hile the judicial and political assaults on the agency made it more difficult for Texas keepers to protect and guide the inmates in their custody, there was absolutely nothing in either the Ruiz opinion or, more broadly in the new legal and political constraints that were foisted upon the agency, that made it impossible to govern prisons well. (At 219)

But he then launches into a sweeping indictment of the court. His

13. DiIulio's views are summarized in his recent essay, "Understanding Prisons: The New Old Penology," 16 Law E Soc. Inquiry 65 (1991).

14. It is interesting to note that two of these four authors have served as guards in Texas prisons. Marquart worked as a guard and wrote his thesis on guards in Texas prisons, and Martin was a guard and later an attorney for TDC and was involved in the Ruiz case for a period. 
claim that the court should have had better information and been more appreciative of the past achievements of the TDC are matters of judgment, but his assertion that the judge and master did not "bother themselves" to consider obvious factors and thus designed an "ill-fitting suit" constitutes a charge of gross incompetence. Dilulio writes:

If the judge were more judicious, his information better, his appreciation for what TDC had achieved in the past less unkind, and his preoccupation with its sores less total, or if he and his aides had troubled themselves to consider the possible unintended consequences of their sweeping actions, there can be little doubt that things would not have degenerated as they did. The new legal framework imposed on TDC was not, as some of the "old guard" have claimed, a "straitjacket"; rather it was more nearly a poorly tailored and ill-fitting suit which the agency was rushed into wearing and which eventually, and predictable, burst at the seams. (At 229)

Similarly DiIulio's assessment of the court's responsibility for the organizational problems and ensuing violence stands in sharp contrast to the assessment of the same events by the authors of the other two books. For instance Martin \& Ekland-Olson observe (at 239) that the increase in violence in 1982 and 1984 seemed to confirm concerns expressed by Judge Justice in 1982 that elimination of unconstitutional policies, procedures, and practices, without careful attention to alternatives, would mean that increased influence of "aggressive and predatory prisoners, disorganized or otherwise."

The difference in the assessment of blame reflects the more general views of the authors. Dilulio can emphasize shortcomings of the court because he believes that the pre-Ruiz system was basically good and that in his haste to root out occasional shortcomings, an aggressive judge threw the baby out with the bathwater. For Dilulio, the building-tender system was a minor shortcoming in an otherwise exemplary system. For the other two sets of authors, the building-tender system was the foundation on which a personalistic, discretionary and terror-based system of control rested. To them it epitomized a prebureaucratic, prelegalistic system of order, effective in maintaining control, but unfair, oppressive, and unrooted in the rule of law. Indeed they see bureaucratic organization emerging only as the consequence of the litigation. In short, Martin \& EklandOlson and Crouch \& Marquart end their discussion of the Texas prison system where Dilulio began, with a description of a well-organized bureaucracy.

\section{Yackle's View of Alabama}

Larry Yackle's Reform and Regret may help resolve these contradictory 
views of the Texas system. His book is an account of the Alabama litigation in which Judge Frank Johnson found that the "totality of conditions" in the state's prisons violated the Eighth Amendment's prohibition against cruel and unusual punishment. A law professor and sometime attorney for the plaintiffs, Yackle focuses on the litigation process and the political responses it generated. He is particularly good in describing the plaintiffs' strategies, the judge's painstaking efforts to engage the cooperation of state officials, and the responses of these officials.

Yackle also identifies the underlying belief that he thinks animated the fierce resistance from state officials to Judge Johnson's findings. He writes:

Politicians seized on the strategy of placing blame for poor conditions on Commissioner Locke and the Board of Corrections-reviving in the process an idea not widely expressed for a half century but nonetheless part of a primitive creed to which state officials unanimously subscribed. Prisons and prisoners should not need public funding; they should support themselves. (At 107)

This belief, Yackle argues, goes a long way in explaining the resistance to the court order, since it clearly implied significant increases in state expenditures. Another source of political resistance was the ambitions of three of the state's leading politicians-Governor Wallace, Attorney General Baxley, and Lieutenant Governor Beasley. Wallace was campaigning for the presidency, and the other two were scrambling to make themselves credible alternatives to Wallace, who could not succeed himself as governor. The result was that all three exploited the prison conditions case for their own political gain.

A legislative task force was established to review the provisions in Judge Johnson's order, and it issued a report critical of the way the state prison was run as a "family affair" and endorsing most of the provisions in the court's order. The task force also went on to propose a way to implement these changes: Rather than increasing appropriations, the state should exploit inmate labor more effectively, and thus use the income so produced to pay for the improvement. "Such a policy," Yackle observes, "mirrored Alabama's experience with the convict lease system 100 years earlier" (at 119). "Then, the state had generated revenues on the backs of prisoners condemned to the mines, where slave labor was actually profitable. Now, state authorities hoped to make profits in new employment schemes requiring a trained labor force" (at 119-20). Although experts ridiculed this scheme as unworkable, Judge Johnson initially went along with the idea. He did so, Yackle suggests, because he welcomed even this convoluted validation for his order and was anxious to garner public support wherever it could be found. 
Over time, however, the task force's proposal was seen for what it was, one more way to exploit the lawsuit for personal political gain and to avoid having to deal with the hard realities of increasing appropriations to pay for the court-ordered improvements. Despite this maneuvering, the task force's report did draw attention to the issues and thus facilitate increased public support for change and additional resources for corrections. Even the corrections officials themselves came to acknowledge publicly the need for change. And as the court heard more experts, even those retained by the defendants would not defend existing practices and recommended the sort of sweeping changes implied by the order. This shift was facilitated by the reports of the Prison Implementation Committee that Judge Johnson had appointed to advise him on developments in the case. In an earlier case, Wyatt v. Stickney, ${ }^{15}$ the judge had appointed a Visiting Committee, a large group of experts-selected in part by both plaintiffs and defendants-which examined existing practices and recommended wide-ranging changes. In this prison case, he relied on the same type of arrangement-rather than a single special master that many other judges have appointed in similar cases elsewhere-to advise him on developments within the prison and to monitor compliance with his orders. Composed of prominent state officials as well as nationally recognized corrections experts, the committee added considerable legitimacy to the court's orders and was extremely helpful in reviewing the steps the state took to comply. Yackle's book does a marvelous job in charting the slow process of bringing the state around and the role this committee played in doing so.

Like a good administrator, Judge Johnson never lost sight of his goals and exhibited great patience. Slowly but surely, intransigence and recalcitrance gave way to ambivalence and paralysis and then to grudging compliance. Yackle's is not a story of judicial triumph so much as of judicial endurance. Toward the end of the book, he recalls standing in the prison yard and taking stock of all the changes that had occurred. It is far from an ideal prison, he concludes, but there was no question that conditions are much better than they had been.

\section{DiIulio's Divergent Interpretation}

For Martin \& Ekland-Olson, for Crouch \& Marquart, and for Yackle, the Texas and Alabama prisons were defective institutions, at best outdated, at worst oppressive and corrupt. While none of the three books views judicial intervention as unproblematic, they all concede the need for it, given the existing conditions in the two prison systems. In contrast, for Dilulio, the Texas prisons were a model of good administration. In Dilu-

15. Wyatt v. Stickney, 325 F. Supp. 781 (1971). 
lio's view, they had but one defect-the building-tender system-and even the problems with this system were only potential ones as long as a strong administrator was in charge. Dilulio's attitude toward the courts is one of guarded condemnation but, even more, of frank bewilderment: Why would a federal judge find so many violations and impose such an extensive remedy on one of the nation's best-run prison systems?

When compared to the three other studies, as well as to a variety of other works on American prisons, Dilulio's perspective can properly be labeled idiosyncratic. But the term "idiosyncrasy" implies that there is something wrong with this perspective, that we ought to dismiss it, and subscribe to the more common one, both as a picture of reality and as a guide to correctional policy. But Dilulio's divergence from the multitude is not sufficient ground for this assessment. It is also possible that he has perceived some aspect of his topic that other commentators have missed.

Evaluation is a highly interpretative enterprise, structured by our preempirical conceptual framework, our forestructures of understanding. Much of this framework is a shared cultural phenomenon, but some of it may be unique to the individual as well. An evaluation controlled by a pre-empirical framework that is unique to the individual, or not widely shared, is an idiosyncratic one. Its divergence from other interpretations is not the result of different observations or a justifiable reasoning process but of a conceptual starting point, one that shapes the author's vision. To conclude that a particular interpretation is idiosyncratic, one must identify the controlling premise and trace its effect on the author's work.

Dilulio's book reveals that he does have such a controlling, pre-empirical premise; while this premise is not unique, it is rather different from the framework used by most other scholars in his field, and certainly from the authors of three other books under consideration here. It is a commitment to order, and, more specifically, to quiet, cleanliness, and respect for authority. Dilulio is not simply committed to control and decisive management, as he asserts. He also yearns for order; he wants things to be neat and in their place, to function with a hushed reverence for authority. $\mathrm{He}$ is enthralled by the calm, self-confident exercise of power.

This pre-empirical commitment is apparent from the first page of his book, where he describes the horrors he encountered in his visit to Walpole prison. "Inmates roamed about virtually unimpeded," he writes. To clean out a "trashed" cellblock, prison officers "wearing rubber boots and carrying shovels waded ankle-deep into the mess and were showered with insults and debris and human excrement." No one would find this an appealing prospect of course, but the fact that Dilulio begins with this negative example, using a prison that is not even part of his study, is indicative.

The theme continues through the book, focusing on less obvious 
abuses. For example, Dilulio complains that in Michigan, the bête noire of his study, the inmates' cells are "bursting with all manner of personal property-television sets, radios, games, books, clothes, sewing machines, and so on." In addition, the "inmates are in every imaginable garb. Few wear their state-issued 'blues and shoes.' Many are in 'cool threads'-silky shirts, expensive (but untied) sneakers, one to three hats (usually baseball caps) on their heads, and gold chains." The California system incites his ire for a different sort of disorder: "If, alas, you were blindfolded and taken to the building that is headquarters for the California Department of Corrections, you would not have the foggiest idea where you were.... [I]f (as I did) you missed the state flag flying in front and the unobtrusive nameplate, you would be sure that you were standing before a store in a shopping mall. All around you, you would see stores and shoppers." What offends Dilulio about the Michigan and California prisons, even more than their lack of order, is the lack of respect for authority, the surly absence of subservience that the prisoners-and headquarters architecture-display.

All this serves as a contrast to Dilulio's account of the ideal prison system-the Texas Department of Corrections, in its pre-Ruiz era. In Texas, DiIulio reports, the prisons were clean and quiet. "Inside the Texas prison you will see inmates in white, officers in grey, and senior officers wearing various signs of rank." The inmates' cells are "spartan." In the headquarters building, "you would probably know that you were someplace having to do with prisons." There is a showcase displaying prisoners' handmade weapons, and a 31/4-foot-long rawhide belt, "once used to administer whippings of twenty lashes to those guilty of rule infractions." "Clean-shaven men in the crisp white uniforms, names written in black over their shirt pockets, [are] busily washing windows, polishing floors, and nodding a greeting to each person who walked by them."

In the Texas prisons, moreover, the inmates know their place. "When the men in white speak to the men and women in grey, they usually do so in a calm voice." Violations of this rule are followed with a disciplinary report. "Rather than automatically sympathizing with [an inmate's] complaint, Texas prison workers are more likely to weigh its legitimacy and remind the inmate of the limits both of the institution's resources and the inmate's rights."

Dilulio's adulation for the orderliness and discipline of the Texas prison reaches its height in his description of the Huntsville "Walls" unit, and its warden, Jack B. Pursley. This extended passage is reminiscent of a devout believer's description of a saint. General statements of unreserved praise are punctuated by quotations of the great man's sayings, anecdotes to illustrate his virtues, and affectionate references to his personal traits, such as his fondness for country music. Throughout, the dominant image 
is that Pursley maintains order, cleanliness, and discipline, down to the smallest details. We see Pursley monitoring the distribution of towels, Pursley altering procedures for employee meals so that a "nurse lady" who brings her own lunch doesn't take two pieces of bread, Pursley lecturing subordinates who performed the prisoner count incorrectly, Pursley ordering new batteries for the smoke detectors.

Being pre-empirical and in some sense, preconscious, Dilulio's unrestrained admiration for order, cleanliness, and obedience does not operate as separate, independently defined criteria, but rather coalesces into Dilulio's image of a good prison. Because it is pre-empirical, this image is not derived from the Texas Department of Corrections or any other observed institution. Rather, it represents a conceptual starting point that then is fastened on the TDC. Indeed Dilulio's research was carried out after the Texas control model had disintegrated, and, thus, he never directly observed the system he admires so much.

It may be that Dilulio's view of the Texas system is no more of a reconstruction than any other description. What makes it seem so odd is that Dilulio's reconstruction is driven by a set of values that are truly idiosyncratic. Most people who write about prisons, while recognizing the need for order, are not nearly as fond of it, and not nearly as committed to hierarchy and obedience, as is Dilulio. While they agree that prisons should be clean and orderly, they are not as offended by untied sneakers, administration buildings in shopping malls, and insolent behavior by prisoners. Nor are they particularly enamored of white uniforms, displays of rawhide belts, and wardens who monitor minute details of prison life. Moreover, they are concerned with other issues that Dilulio tends to undervalue, such as the legal rights of prisoners, the abuse of authority by prison officials, and the need to provide health services.

Dilulio is far from unsophisticated, however. There are passages in his book where he acknowledges these issues and, indeed, proclaims their importance. There are other passages where he seems to present a reasoned argument for his own vision and marshals evidence on its behalf. Order, he argues, is the precondition for any other benefits that prisoners receive; if the prison is in chaos, if the inmates are really running the joint, then rights, services, and controls on public power become meaningless. It thus seems possible that his preference for order is a rationally justified position, despite the fact that his presentation of it, his imagery, and his descriptions seem to stem from pre-empirical values.

But Dilulio's book reveals a number of major gaps in reasoning which indicate that his divergent views really are starting assumptions rather than justified conclusions. Consider, for example, his lengthy chapter entitled "The Quality of Prison Life." He begins, quite reasonably, by identifying three elements by which the quality of prison life can be measured: 
order, amenity, and service. All three are important, he declares, although the latter two are difficult to measure. He proceeds to compare the three prison systems in his study with respect to order and finds Texas the most orderly. He then tests his hypothesis that order is the result of prison management by examining various explanations for the greater orderliness of Texas prisons, such as characteristics of the inmate population, level of expenditures, prison architecture, and so forth. Having rejected each one, he concludes that prison management does matter and then proceeds to discuss the subject in the remainder of the book. However, he never returns to the assessment of amenity and service. He considers these two issues only as one rival explanation of the reason prisons are orderly, and he rejects it together with the others. But he never evaluates amenity and service on their own terms, despite having identified them as two main elements of prison life. All 40 pages after the introduction are devoted to order.

This is particularly striking because the Ruiz litigation focused heavily on amenity and service issues, as does prison litigation involving other systems. The quality of food and medical services, the levels of crowding, the availability of educational and vocational programs, and the number of unnecessary intrusions on inmates' lives were issues that appeared again and again in the multitude of suits and judicial decisions.

Even more notable are Dilulio's efforts to account for Texas's building-tender system. This system was not only regarded as a major abuse by virtually all other observers, but it clashes with Dilulio's perception of the Texas prisons in a number of important ways. Dilulio states that the Texas prisons were clear and forthright about their methods, but the building tenders were concealed from Judge Justice and the public. He states that Texas maintained a strict separation between the guards and the prisoners, but the building tenders sat astride that line, effectively obliterating it. Dilulio says that Texas represented the negation of the belief that prisoners run prisons, but the prisoners selected as building tenders did exactly that. To account for these apparent anomalies, Dilulio explains that the building tenders were tightly supervised in the pre-Ruiz days, that they were a "rotten crutch" for the Texas system, that they were not truly a part of the system, that the department should not have tried to retain them, and so forth. None of this seems sufficient, particularly when one considers that the use of prisoners as guards was found in virtually every southern prison and was invariably a source of horrible abuse. What seems to be at work in Dilulio's account is a classic case of cognitive dissonance. Confronted with material that clearly fails to fit the image he has constructed, he resorts to a variety of devices, such as minimizing its effects, denying its importance, and wishing that it had never existed.

Yet a third gap in Dilulio's reasoning is his conflation of order and 
bureaucracy. He repeatedly describes the Texas control model as a bureaucratic one, presumably because bureaucracy, for all its negative associations, carries a connotation of lawfulness and rationality. In addition, Dilulio is influenced by James Jacobs's study of Stateville (Illinois) Penitentiary, just as the Texas prisons were influenced by Stateville's warden, Joseph Ragen. Jacobs presents the changes in Stateville, induced by lawsuits and other outside forces, as a transition from a patriarchal regime to a bureaucratic one. Dilulio wants to claim the benefits of this process for the pre-Ruiz regime in Texas. By presenting this regime as bureaucratic, Dilulio is able to imply that Judge Justice's decree accomplished virtually nothing that was positive or even neutral. The Texas prisons had no need for Judge Justice's remedies, because they were orderly and bureaucratized before he started.

But others do not described the pre-Ruiz Texas prisons as bureaucratic. Indeed, by Dilulio's own account, they displayed a highly personal style of leadership that is virtually the antithesis of bureaucracy. "Walking George" Beto, who regularly inspected every prison and employed the formidable force of his personality to secure obedience and conscientiousness, seems to epitomize Weber's charismatic style of authority. The same pattern, on a smaller scale, appears in Dilulio's account of the Walls unit and of Jack Pursley, with his bread and towel supervision. When one adds the building tenders, the use of prisoners as "houseboys" and other personal attendants of the officers, the harsh and arbitrary punishments and various other factors that DiIulio underplays or omits, the picture that emerges is a very different one. It is one of traditional authority.

In reality, bureaucracy is not distinguished by its degree of control over the subject population but by the nature and degree of control it exercises over the officials in power. "Hierarchy," as Weber uses the term, does not refer to the superior position of the ruling group-that relationship exists everywhere but in the fantasies of the Levellers and the Fifth Monarchy Men-but in the internal organization of those rulers. The rationality and regularity of bureaucracy lies in the rules that govern official behavior and the requirements that those rules be justified as instrumentalities for achieving some recognized purpose. In this sense, the pre-Ruiz regime in the Texas prisons was not bureaucratic. Its quality depended on the nature of its leader; the leader himself was subject to few constraints, and his subordinates were subject only to the constraints the leader wanted to impose. At its best, bureaucracy secures the rule of law by subjecting everyone, including the organization's leader, to definitive rules. Prior to Ruiz, the Texas prisons clearly did not possess that characteristic.

If one defines order as Dilulio does-the degree of control that the ruling body exercises over its subject population-there is no necessary relationship between bureaucracy and order. To be sure, a pre- 
bureaucratic regime tends to control fewer aspects of its subjects' lives, leaving more to culture or tradition. But such a regime, if effective, can certainly control whatever it chooses to control by using the necessary levels of force. Conversely, a bureaucratic regime can be chaotic or disorderly, depending on its norms and effectiveness.

In short, Dilulio's description of the pre-Ruiz Texas prisons as bureaucratic is simply another reflection of an idiosyncratic set of presuppositions. For him, the Texas prisons are idealized images of the order, cleanliness, and respect for authority he so desires. Other positive attributes, such as bureaucracy, simply become attached to his image, whether they fit or not.

\section{The Consensus View: Martin \& Ekland-Olson, Crouch \& Marquart, and Yackle}

The three other works reviewed begin with the belief that prisoners, despite their conviction, are not slaves of the state, but possess certain basic rights-including the right to fair treatment, adequate living facilities, necessary medical care-that can be asserted against prison officials and enforced by an outside authority. They further share the view that prison officials should be subject to binding controls on their behavior. Finally, all subscribe to the view that prisoners ought to be given opportunities for education and vocational training, even if these opportunities do not necessarily lead to rehabilitation. This set of views is highly familiar, of course. It is shared by many U.S. prison systems, by the American Correctional Association, and by the federal courts.

Prior to 1965, there was one major group of prisons that were based on different views and premises. These were the southern prison systems, which continued to treat prisoners as slaves of the state. This was not only a legal position but also an economic one. Prisoners should work to support the institution or provide services for its officials, and the institution as a whole should generate some economic benefit for the state, or at least be self-supporting. Its purpose was not to provide services to the prisoners, and any basic services that were provided were set at levels necessary to keep the prisoners working. The model for these southern prisons was the plantation rather than the bureaucratic service institution. Indeed the origins of this model were literally rooted in the plantation system adapted to post-Civil War conditions in the South. ${ }^{16}$ The modern Texas and Alabama systems still operated under the residue of this earlier vision.

16. See, e.g., Mark T. Carleton, Politics and Punishment: A History of the Louisiana State Penal System (Baton Rouge: Louisiana State University Press, 1971); Blake McKelvey, American Prisons: A History of Good Intentions (Montclair, N.J.: Patterson Smith, 1977); Malcolm M. Feeley, "The Significance of Prison Conditions Cases: Budgets and Regions," 23 Law \& Soc'y Rev. 273 (1989); Malcolm M. Feeley \& Edward Rubin, "Federal State Relations and 
According to Martin \& Ekland-Olson, Crouch \& Marquart, and Yackle, judicial intervention in the Texas and Alabama systems was a qualified success. It did not generate ideal institutions, but it replaced an unacceptable model of prison administration with one whose basic premises were justifiable. The prisons that resulted were managed with different levels of skill-just as the judges who intervened did so with different levels of perspicacity-but both the intervention and management was based on a commitment to individual rights, to the control of official power, and to the provision of vocational and educational opportunities to prisoners.

Thus, the assessment offered by these three books differs markedly from Dilulio's, but the difference is much deeper than program evaluation. It extends to the basic perception of the reality that is being observed. For DiIulio, the Texas prisons represented an ideal model with a single, remediable defect, and judicial intervention was an unnecessary and destructive event, motivated by ignorance or naive sympathy for prisoners. For Martin \& Ekland-Olson and Crouch \& Marquart, the Texas prisons were a well-managed version of an unacceptable model, and the courts intervened to impose a different model that represented widely shared views about legality and punishment. And for Yackle, the Alabama prisons were a poorly run version of this unacceptable model. Thus, in all three of these books the authors, and the judges in the cases they examine, rejected not only conditions they found but also the underlying vision of the prisonthe plantation model and the notion of the prisoner as slave of the state implicit in this model-that was embraced by correctional administrators in Alabama and Texas.

These differences in perceptions are based in different pre-empirical assumptions. Dilulio begins from the premise that order and cleanliness are the primary virtues of a prison, while the other authors emphasize prisoners' rights and lawful authority. There is no immediately obvious way to make a definitive choice between these different views. Any effort to evaluate them by some overarching standard would carry us deeply in philosophic inquiries that lie beyond the scope of this essay. We would simply note that the values that lie behind the books by Martin \& EklandOlson, Crouch \& Marquart, and Yackle also lay behind the judges', and that they can be fairly described as our society's basic values in this area. The premises of Dilulio's work are not unheard of, but they are found in relatively small subgroups, and they seem wrong to most Americans at this stage of our history.

Prison Administration," in Harry Scheiber \& Malcolm M. Feeley, eds., Power Divided: Essays on the Theory and Practice of Federalism 63-75 (Berkeley, Cal.: Institute of Governmental Studies, 1989). 


\section{Conclusion}

John Dilulio's Governing Prisons advances the thesis that "prison management matters." It does, but the purpose of prison management matters more. A prison based on the values of order and control can be well managed, as the Texas prisons were, or badly managed, as were Alabama prisons, but that alone does not yield an adequate assessment, because we must ask about the purpose of this management. If those purposes are unacceptable, the result will be unacceptable as well, regardless of the technological skill with which those purposes are realized. That is what the federal courts decided about Texas-that however well the state ran its prisons, it was doing the wrong thing.

For most of us, prison regimes must be based on premises of prisoner's rights, control of official power, and the availability of opportunities for prisoners. Once those premises are chosen, prison management really matters and can, as Dilulio argues, make a difference, because improvements in the technology of operations can produce a "better" prison. However, the question of management, of technology, cannot be framed until we know its purposes. At the same time, management is extremely important within the context of those purposes. It is not enough, in our complex, technocratic age, to have good ideas and attitudes; we must also know how to use the technology to run institutions, and to implement our social vision of them.

Judicial intervention is an odd way to reform prisons, but judges were not unaware of, or unsympathetic to, technological needs. Despite the language of individual rights, judicial efforts are very much in the tradition of institution building: clarification of basic mission, insistence on tight and responsible administration, cajoling the legislature for increases in appropriations, garnering of political support for change. These are not goals explicitly articulated by the judges in those cases; rather, they are loosely and intuitively embraced by the courts. But they have animated most courts that intervened in prison, and they have done so even though there was no clear doctrinal justification for them. Indeed, in the "organization society" the protection of individual rights is only meaningful in the context of strong bureaucracy, for bureaucratic organization, in contrast to other forms of authority, substitutes the rule of law for the will of the person. If we are correct in this assessment, then the lasting impact of the prisoners' rights movement will be stronger, better organized, and more efficient institutions. 
HeinOnline -- 17 Law \& Soc. Inquiry 1461992 